\title{
Legal Solidarity: Historical, Religious Moral Background and Perspective of Implementation in the Digital World
}

\author{
Alexey I. Ovchinnikov ${ }^{1,2}$, Tatiana S. Yatsenko ${ }^{3}$, Armen K. Oganesyan ${ }^{4} \&$ Vasily M. Emelyanov $^{5}$ \\ ${ }^{1}$ Department of Theory and History of State and Law, South Federal University, Russia \\ ${ }^{2}$ Department of Constitutional and Municipal Law, Russian Presidential Academy of National Economy and \\ Public Administration, Russia \\ ${ }^{3}$ Civil Law Department, Southern Federal University, Russia \\ ${ }^{4}$ Department of Biomedicine, Veterinary and Ecology Sciences of RUDN University (Sochi branch), Russia \\ ${ }^{5}$ Moscow Academy of the Bar and Notary Office, Russia \\ Correspondence: Alexey I. Ovchinnikov, Head of the Department of Theory and History of State and Law, South \\ Federal University, Russia. E-mail: k_fp3@mail.ru
}

Received: June 22, 2020

doi:10.5539/jpl.v13n3p142
Accepted: July 10, $2020 \quad$ Online Published: August 17, 2020

URL: https://doi.org/10.5539/jpl.v13n3p142

The article is prepared with the financial support of the Russian Foundation for Basic Research in the framework of research project № 19-011-00820 (a).

\begin{abstract}
With the help of another technological revolution the modern world is suffering from a new radical breakage of all areas and ideals, which include legal principles, ideas and values. The most important amongst them is the principle of the legal solidarity with the long history that has already been rooted in the Bible's System of Things and Christianity. The main prerequisites of the legal solidarity as well as social and cultural prerequisites of the legal solidarity in the studies of the legislators in Russia and foreign authors are considered in this article. Suggestions of the new stage of solidarity realization in the legislation including digitalization, which allows to implement targeted social assistance and to eradicate the main vice of solidarity - passiveness and paternalism of the social state citizens, are being made.
\end{abstract}

Keywords: history of the legal ideas, legal culture, legal ideology, legal solidarity, digital technology, social law

\section{Introduction}

The problem of further implementation in the legal solidarity in the conditions of the new digital world is acquiring special relevance owing to the crisis of the Russian state and the law caused by the world economic crisis as well as the problems with modernisation of the Russian legal system after the Soviet state breakdown.

Reformers of the 1990s have chosen a course to introduce western liberal models of the state and law excluding the Russian legal culture, legal mentality and legal awareness that are highly dependent on collectivism and solidarity. Unaccustomed is the individuality principle on the basis of which foreign political and law institutions are functioning. Already in the 90's scientists started talking about the necessity to revise the course of nation's development.

Two points of view prevail in modern Russian and foreign juridical literature. One point of view is based on classical postulates of liberalism and it insists on inability to build a solidary type of society without eradicating the main flaw of socialism - "business passivity" and reliance on states in solving personal economic issues. Within the framework of it, legal solidarity is rejected owing to rejection of its collectivistic and socialistic aspirations, predominance of the general over the private. The other point of view is based on the idea of social mutual assistance and social human nature that allows building a social justice society. Its supporters are pointing out the crisis state of capitalistic society which is built on individualism and liberalism as long as emphasising on the need for socialisation of the market economy and private property. We will try to justify an opportunity to overcome this collision through such opportunities that are provided by digital revolution of the sixth technological mode. 


\section{Literature Review}

Criticism of the post-soviet modernisation in domestic legal system is carried out in a number of scientific monographs and articles of the last two decades. For example, already in 1995, V.N. Sinyukov published his own monograph dedicated to domestic legal system in the reform period criticizing pro-Western liberal vector in the development of our state. As noted by V.N. Sinyukov: "value of the law in Russian legal awareness is not in providing formal legality, but in its achievement of identity with a deep image of its own world view" (Sinyukov, 1994: 217). According to the scientist, Russian independent legal policy is in the formation of the legal system and in the beginning of national legal culture - guarantee of its independence from western countries and sovereignty.

Subsequently many authors have come out with the criticism of chosen liberal course. For example, A.Y. Mamychev, A.I. Ovchinnikov, have noted that in Russia it is necessary to have synthesis of political and legal traditions, legal archetypes, state law mentality and legal culture in the process of making not liberal but national legal statehood - "states of truth", institutions of which will possess solidarity (Baranov, Mamychev, Ovchinnikov, Komarov, Samoylichenko, 2017; Baranov, Ovchinnikov, Mamychev, Plotnikov, 2017; Apolsky, Baranov, Mamychev, Mordovtsev, Ovchinnikov, 2017). Other authors have pointed out, that in domestic statehood and legal culture that is traditionally committed to orthodox and spiritual ideals, law is identical to the concept of "truth", which integrates perfect, morally approved behaviour with the idea of truth, even if such behaviour contradicts the law (Velichko, 1999; Sorokin, 2007; Vasilyev, 2012).

In his famous report, in St. Petersburg juridical forum in 2019, the Chairman of the Constitutional Court of The Russian Federation V.D. Zorkin has turned attention to the necessity to reconsider fundamental theoretical concepts, which determine state law development of the country. First of all, attention is attracted to author's appeal to consider national and cultural identity, political and legal mentality in constitutional and legal development of the country. Author is writing: "When tired of numerous displays of such relativism in postmodern politically volatile law, a whole line of countries comes to a realization of such circumstance, excluding sociocultural normative values' specification, which was historically established in the basis of one or another national legal system, that no legal development is possible. A solution to postmodern law challenges was the doctrine of national identity, which is called differently in various legal systems, but in its basis we comes to realization of the significance in normative values' foundation of constitutional system in one or another state" (Zorkin, 2019). Scientist focuses on how society faces the new crisis of legal awareness caused by breakdown in accustomed valuable representation and stereotypes. This breakdown is caused by the dictation of "consumer society" values, lack of ideas, blind imitation.

When talking about postmodernism and hypermodernism the scientist indicates that the problem of social justice is especially urgent nowadays, which appears in social stratification growth, both inside of many countries and on a global scale - between different regions of the world (Zorkin, 2018;2019). He also points out to a possible crisis of solidarity and sociality in the conditions robotization and digitalization, that is "kicking out" billions of people, who lost their workplaces due to their replacement with new technological devices. In his opinion, solidarity is capable of preventing fatal consequences of digitalization.

One another judge of The Constitutional court of The Russian Federation N.S. Bondar, in the last years emphasizes in his articles that nowadays preservation and development is gaining importance in all wealth of national cultural features of Russian nationhood and its legal system. He also criticizes uncritical reception of liberal values in western culture. Russia should not be a recipient of old constitutional samples even if they became classics. It has to be the maker of the modern democratic constitutionalism that meets the needs of national society and state (Bondar, 2011).

In his monograph, dedicated to constitutional economy, V.I. Kruss is offering to rely on solidarity principle in studying fiscal economic obligations. You cannot but agree with the fact that fiscal policy of the state looks organic in the conditions of awareness of social unity. "The ideal of responsible harmonization in constitutionally inseparable public and private interests is embodied in the idea of solidarity" (Kruss, 2017).

Overall, we must admit, that in juridical science there is already a consensus regarding the cause and nature of failures in the reform matter of Russian legal system in the last 25 years. Supposedly, the main cause of errors in the formation of the law in contemporary post-soviet modernizable state, is noncompliance with continuity in state legal development, ignoring legal culture and distinctive basis of Russian law (Vasilyev, 2015; Medushevskaya, 2010; Timofeyev, 2018; Igolnikova, 2014; Simashenkov, 2016).

Critical attitude towards the ideas of legal solidarity is expressed by a famous Russian legislator T.Y. Khabrieva: "Lawyers are still harmonizing the ideas of individuality and collectivism in the context of problems in providing social justice and legal identity, pondering their synthesis models, busy searching for or constructing optimal 
models, that are able to provide constitutional identity of the state when referring to the ideas of solidarity" (Khabriyeva, 2018). However, solidarity, in her opinion, contradicts modern liberal legal values. In her opinion: "Contemporary civilizational transformations determine highlighting of the idea of humanism and transhumanism, their struggle and agreement. Apparently, you have to look for the origins of the formation of the new legal values right here. Until they are found, understanding of the law as universal norm of equality for all must remain the basis of the law (as it started in the era of Renaissance, Reformation and Enlightenment, which formed the idea of law as a rational picture of the world, where various social forces are balanced in a democratic way)" (Khabriyeva, 2018).

\section{Research Methods}

Approaches and methods of scientific theoretical, systemically structural, conceptual analysis of legal ideas, views, judgements, doctrines and concepts are theoretical methodological basis of a research. During examination of prerequisites of legal solidarity in the history of political and legal studies, there were applied research methods and receptions of historical theoretical comprehension of philosophy of the law: contextual, hermeneutic, axiological, argumentative logical and comparative methods, techniques of their cognition. Methods of philosophical legal analysis were used during interpretation of legal ideas in juridical science in the XIX-XX century. Civilizational sociocultural approach to law allowed identifying national features of Russian theory of the law and impact on its becoming of a spiritually moral identity of Russia. The most correct method in establishing nationally cultural vector of state legal development in our country is the method of legal anthropology or anthropological method of cognition of the law. That is what allows to establish a connection between ethnic everyday, linguistic, mundane legal awareness and legal culture.

\section{Solidarity in Ancient Israel}

Legal solidarity has an ancient history. In the essays of Bible researcher A.V. Lopukhin there is an indication to theocracy, as if it is a social order in Ancient Israel, which leads to social solidarity. We see in it a completely different understanding of theocracy, rather than accustomed for most researchers its definition through the authority of hierarchy. The researcher critically evaluated definition given by Flavius Josephus: "Theocracy is not some special state form of government as opposed to monarchy, oligarchy or democracy, as seen by Flavius Josephus, who was the first to put this term into use, but expresses only a special attitude of Jehovah towards people as if they were the chosen ones - attitude that was expressed in His spiritual supremacy over people through obligation to preserve contract and implementation of legislation" (Lopukhin, 1879: 336). The researcher understands theocracy in an extremely wide way: as an organizational principle not only of state legal or political life, but as an all-encompassing and comprehensive paradigm of social structure of life of ancient Jewish people.

Thereby, A.P. Lopukhin writes: "theocracy must be understood not as a form of government, but as a principle that gives general norm to public life, when harmonizing with it, people had absolute freedom in development and were able to make themselves according to their needs, historical circumstances and the conditions of all private forms of state and public life" (Lopukhin, 1879: 336).

In theocratic concept the state has special features: it is based on the most sublime start, on the faith in common for all Creator, wanting to save his people from tragic death amongst humankind stricken by sin and who had signed a contract or testament, who then became the king of Jewish people. Lopukhin emphasizes that the main goal of creating Jewish theocratic state was preserving monotheism among pagan polytheistic cults with their idolatry, immoral perversions, sacrifices and superstitions. Jehovah was becoming a legislator, who created not only a state but also the law, forming legal awareness and legal culture of ancient Jewish people. Theocratic principle was, if I may say so, state forming in the state of Moses.

Theocratic principle of building a state played a huge role in formation of legal culture and legal awareness of Ancient Israel. Above all, this principle laid the foundation for ancient Jewish for representation of equality of all before the law and public solidarity and became basic for the principle of equality. From religious equality and solidarity of all Jewish before Jehovah follows equality and solidarity in all other areas of public political life: legal, economic, social. In this sense, theocracy of Ancient Israel may be considered as a prototype of European democracies and conceptions of human rights. Thereafter, the first Christian communities were building their life following the principles of biblical solidarity.

Lopukhin consistently considers various areas of refraction in theocratic principle in providing with solidarity. He pays special attention to the land tenure issue. Fairly believing, that farming helps to build a strong powerful statehood on the basis of moral qualities of citizens: due to patriotism of the ones who work on the land and hard work, that can be considered as one of the most important moral qualities of personality. Lopukhin is offering to consider land rights in Ancient Israel as an example of theocratic influence on legal understanding, principle of 
equality, solidarity and fair distribution of wealth. The fact is, that every member of state, every family were prescribed land tenure - equal tenure of land. When in the countries of the Ancient East we see, that landowners were only privileged levels of society, the elite, nobility, then in Ancient Israel every Israeli was an owner of land plot. That is why the state of Moses, as fairly emphasized by A.P. Lopukhin, is formed on the principles of social economic justice. Thanks to the fact, that in the agreement with Jehovah the whole population takes part, every resident of Ancient Israel owns land on equal rights. That is why there is not any legal reason to seize the land, juridical processes of land seizures, occupations of the land of others. The land was equally divided between the Israeli. As criteria to allocate the land, generational division has started. If some owner has bought the land of impoverished landowners, then upon expiration of a certain period, every 50 years, sometime ago sold land was returned to the very first landowner. Thereby, the recovery of social justice was guaranteed and there were obstacles for emergence of large owners, oligarchs. This principle might be considered as a beneficial influence on a matter of social justice, that was solved in the state of Moses with the help of jubilee mechanism and other juridical obstacles for transition of wealth to the same person. Thus, there was no class division, that, for A.P. Lopukhin who was living in the period of pre-revolutionary unrest, was extremely important.

The equality of all before the law was quite normal for Ancient Israel and completely astonishing for the states of Ancient East. There was not anyone in Ancient Israel who was completely deprived of civil rights, like institution of slavery in Ancient Rome. The law recognized every member of state as a personality of full value. If we are to talk about slavery, then it can be seen how clearly the law limited mistreatment of own slave: slave owner would lose any right for the slave and even set them free as a result of such mistreatment. The truth is, priests had a special status, that originated from the generation of Levin. But they did not have as much privilege, as they had responsibilities, which they carried before the God and the people. That is why there could not be any supremacy.

Concepts and principles, formulated by A.P. Lopukhin when analysing The Five Books of Moses and the Bible, of theocratic legal thinking, as it can be seen, were reproduced in different stages of state legal evolution of western and eastern societies. Medieval idea of power, law, social justice, that was set under influence of theocratic ideal, also became a definition in development of European legal thinking and political practice. The ideas of agreement, democracy, equality and virtues of a human were used in the reforms of the New age and Enlightenment. Moreover, formed institutional basis of power and public interaction was transformed in time, but reached the present, saving the basic functional idea of political and legal institutions, however, most theoretical conceptual and methodological provisions laid the basis of modern legal science.

\section{Formation of Legal Solidarity in the XIX-XX Centuries}

Ideas of solidary, social, collective law has been deeply developed in France, Germany, Russia in the end of XIX beginning of XX centuries by L. Bourgeois, E. Durkheim, lawyer L. Duguit, O. Gierke and others. The cause of it was disappointment in the ideals of rationalistic concepts of natural law and bourgeois revolutions with their individualistic values. French solidarist L. Duguit has been using this term in the title of his monograph "Social law, individual law and the transformation of the state" (Duguit, 2015). German legislator O. Gierke (1841 - 1921) had offered the term "social law", which determined, unlike private (individual) law, internal life of unions, which did not have private (state) character. In Russia this idea was followed by L.S. Tal (1867 - 1933) (Tal, 1915: 8 - 9, 20, 1916: 42), and a L.I. Petrażycki, who noted, that there is a unofficial law of social service, which, in the period of his life, was already broadening horizons of non-state lawmaking at the expense of collective labor agreements, common law of labor unions, institutions of industrial democracy (Petrażycki, 1913). The part of Petrażycki in the formation of social law studies was pointed out by G.D. Gurvich: "L.I. Petrażycki has been preparing a path to modern theories of social law, as a law of pure integration, which differs from coordination law (private law) as long as subordination law (public law)" (Gurvich 2004: 352). Gurvich also noted, that "the use of this term especially reasonable, because it has a long and a glorious history" (Gurvich 2004: 186).

In the XIX century many representatives of Russian law sociology were convinced conservatives and they followed solidaristic interpretation of public life, since special part in development of Russian sociological jurisprudence, among representatives of which were such scientists as D.I. Meyer, F.L. Moroshkin, N.I. Krylov, P.G. Kalmykov, V.N. Leshkov, M.M. Mikhailov, was provided by worldview ideas of German conservative philosophy. Organicism, conservatism and romanticism had a big impact on Russian legislators in XIX century, who, exploring the common law, had laid the foundation for Russian law anthropology, owing to its denial of subjective rationalism and to defense of objective historicism, which transferred research interest and attention from a part to the whole - from an individual to a society, people, and, in the end, to a civilization. Orgasmic social philosophical thinking of German philosophers, such as Gerder, Schelling, Krause, influenced jurisprudence in Germany and formation of legal solidarity, which sought to consider a society as an organic whole, a unified system, in contrast to mechanical picture of the world and individualism, spread in the era of Enlightenment. Beside the German romanticism and historicism, sociology and 
anthropology of law in Russia was influenced a lot by the French organic theory of society, which slightly differs from the organic theory of state in great positivism. Beside the organic theory of society, formation and development of Russian sociology and anthropology of law was also majorly influenced by the works of representatives of German romanticism - August and Friedrich Schlegel, Johann Fichte, Friedrich Schleiermacher, as well as ideas of historical law school of Tibo, Hugo, Savigny, Puchta, Jhering, whose ideas impacted the studies of Guins on emergence and development of law, legal progress, which flows in wave-like movement: first in order to adapt to conditions that were created, then in the form of struggle between an established order and a pursuit to its update.

Before the revolution in 1917 in Russia in juridical science solidarism was extremely popular. First of all, its ideas were developed by N.N. Alekseyev, A.A. Goldenweiser, B.A. Kistyakovsky. In particular, A.A. Goldenweiser thought that the moment of creation in social life is not the right, but the responsibility, and if a person has any rights, then only in giving good and beneficial to the society. Wherein objective law is considered as "the norm of social duty of a person", responsibility is a constitutive element in legal relationship, and subjective law is just an execution sanction of this responsibility. Thus, performance of duty is a target, protection of the rights is just a way. State must provide conditions for disclosure and realization of social value of a person (Goldenweiser, 1952: 171). It should be pointed out to the ideas of M.M. Kovalevskiy (1851 - 1916), who pays attention to the law and order basis in the ideas of solidarity of members of society, their associations, occupations, and solidarity is based on the division of labour, on the awareness of mutual dependence and the agreements, compromises, arising from here (Kovalevskiy, 1997: 83-84).

\section{Modern Solidarity}

Political legal study of solidarity is considered by some authors as the basis of Russian modern constitutionalism. Approaches offered by them describe constitutionalism as a legal acknowledgment of social solidarity: 1) social solidarity is considered in a context of classical principles of constitutionalism (concepts of legal, democratic, secular state; modern concepts of human rights and state sovereignty, guarantee of rights of minorities, national representation and direct democracy, division of powers, federalization, secularization and clericalization); 2) social solidarity defines further development of fundamental principles of constitutionalism (concepts of social state and solidary society, constitutional internationalism and problems in providing international solidarity) (Alebastrova, 2016: 67).

However, serious obstacles occur in the path of constitutionalization of legal solidarity. It is also described in the works of leading scientists: in the conditions of natural legal, liberal individualistic philosophy of the law especially significant becomes adjustment of liberal individualistic approach to legal understanding (dominating in today's world theory and practice), with the help of which it would be possible to bring into the law itself of the idea of solidarity. I.e legal theory and philosophy of the law is needed, which synthesizes, within the concepts of the law, the ideas of individual freedom and social solidarity. Such approach to legal understanding to the greatest degree corresponds to mentality of Russian people, their legal and moral consciousness (Zorkin, 2018a).

For further development of constitutional solidarity scientists are offering to adjust personalistic interpretation of society. An appeal for experience of soviet state construction is very important. In that period there was such a way of correlation of rights and duties which is inherent to solidarity (Titova, 2018).

In the modern juridical literature the principle of solidarity is already reflecting on emergence of ideas of social law Lushnikov, Lushnikova, 2009: 43-51; 2009a: 314-334; 2007). The theory of solidarity is considered as a philosophical core of collective labor law, which constitutes "social law" (Tarusina, Lushnikov, Lushnikova, 2017). Ideas of solidarity already fully define constitutional policy in many countries. As noted by the head of The Max Planck Institute for Comparative Public Law and International Law (Germany) Armin von Bogdandy, in the states of Latin America the emergence of new "transformative" constitutionalism can be seen, it is built on solidarity of members of society, interdependence and indivisibility of citizen rights (Kabyshev 2017).

In Russian Federation the ideas of solidarity are implicitly present in practice of constitutional jurisdiction. Thus, for example, just solidary approach to delimit private and public lies in a number of Regulations and Definitions of the Constitutional Court of the Russian Federation. In Definition of the Constitutional Court of the Russian Federation from the $8^{\text {th }}$ of April 2004, N 169-O, the judges, when considering the problem of good faith in the context of freedom restrictions in the implementation of entrepreneurial activity stated: "in a sense constitutional law, when defending public interest, restricts private interest. These ideas are expressed in the constitutional law through the principle of necessity in fair implementation of own subjective rights (part 1 article 17 in The Constitution of the Russian Federation). Subjects of entrepreneurial activity are entitled to apply, within the freedom of economic activity, various ways of civil law (a bill of exchange, loan agreement, the right to claim a concession, reorganization of a legal entity and so on). Although, when carrying out subjective rights, it should be 
considered, that in this way they might go beyond private ownership and affect the area of public (fiscal) interests. And when obvious disregard of these interests takes place, then misuse of given subjective rights might occur" (The decision..., 2004). In fact, such judgement of The Constitutional Court of the Russian Federation declares solidaristic interpretation of interest balance in public and private law. Now in any act of realization of subjective civil rights it is necessary to follow the principle of good faith towards the public wealth.

In another decision The Constitutional Court of The Russian Federation has taken the side of the state in a review of collision between positions of the articles 13 and 15 of Federal law "About state benefits for citizens with children", articles 10 and 11 of Federal law "About the status of the military personnel", article 32 "Regulations about the order of performing a military service" and the parts 35 and 44 "Regulations about the assignment and state benefit payment for citizens with children (the Case of Markin), when referring, that having a career in military service, firstly, assumes/suggests the presence of certain limitations of his rights and freedom, which are inherent to this kind of civil service and, secondly, performance of duties in providing the defense of the country and safety of the state (The decision..., 2004).

Not all the scientists agree with this direction of legal policy. Thus, for example, D.M. Shchekin, in his analysis of legal tax policy, notes regarding direction of The Constitutional Court of the Russian Federation towards public interests: "When developing this position to its logical completion, it should be admitted, that in the modern Russia, when implementing subjective state law, constitutional obligation to consider public (fiscal) interest" (Shtchekin, 2007). The author reasonably believes, that, in case of acknowledgment of the need in process of realization of citizen rights, public interest should be considered, besides own interest, which is discussed in the article 1 in The Civil Code of The Russian Federation, "we will be forced to state, that we are dealing with with a completely different system of legal landmarks, where the public beginning is introduced even in the core of private law, thereby, making it public and suppressing it" (Shtchekin, 2007).

In reality it is spoken about the value of public interest. But we cannot but agree with the author, that the problem lies in substitution of private law with public one, private interest with public interest. It is thought that the problem is that in the nineties in public legal awareness a serious shift in favour of absolutization of private law, property rights, private interest.

\section{Digital State, Solidarity and Covid-19 Pandemic}

Global trend in favour of social state indicate the right vector of development in legal policy of The Constitutional Court of the Russian Federation. In the period of pandemic we see the efforts of every state in the support of population and business at the same time. Especially fair solidaristic theory of state and law applies to the institute of private property, precisely speaking, to its social function. The principle of solidarity also leads to the new solution of and old dilemma between compulsory vaccination and private self-care. Solidarity is leading to legislative consolidation in compulsory vaccination for the participants of social communication: it must be followed by those, who visits medical institutions, schools, universities, enterprises. And solidarity became the basis in argumentation of necessity in limiting the rights and freedom of human and citizen never seen before in the conditions of introducing digital forms of control over citizens and organizations.

More and more scientists are supporting the criticism of capitalistic course excluding social mission of market economy: in the last three decades the development vector of our state was formed according to liberal ideology, implicitly fixed in the Constitution of the Russian Federation. As emphasized in literature: human rights, freedom from the state, private property, personal wealth and personal interest, moral and legal individualism, market economy, liberal democracy - these are the main landmarks of state legal ideology of our country. However, capitalism and market economy can be completely different in terms of social state.

Social state and solidarity principle appear in the legislation of different countries. For example, in the article 15 in the Constitution of the Federal Republic of Germany it is said: "Property obliges. Its use at the same time must serve for the sake of common wealth" (Constitutions of foreign states..., 2017). In the article 42 in The Constitution of the Italian Republic it is said: "Private property is recognized and guaranteed by law, which determines methods of its acquirement and utilization, also its limits in order to provide its social function and to be available for everyone" (Constitutions of foreign states..., 2017). In many countries of the world social purpose of private property is also fixed. However, Russia greatly differs from these countries with the lack of constitutional burdens of the owners. G.A. Gadzhiyev notes: "The specialty of The Constitution of the Russian Federation, which distinguishes it from The Constitutions of Germany. France, Spain, Italy, is a wide circle of constitutional authority of private owner with the lack of conditions of their social responsibilities..." (Gadzhiyev, 2001: 89).

In the modern juridical literature it is more often talked about social legal policy. It is also discussed in regard to private property. More often the attention is focused on difference in legal mentality of Russian people and western- 
European people, on "communal", conciliar mind of a Russian person. Unlike "absolute property", which suggests that the power of the owner over a thing is completely unlimited and excludes a possibility of any extraneous influence, "relative property", which is inherent to Russian and German, and also Eastern people, is the most extensive and the least limited right for a thing" (Ovchinnikov, Ovchinnikova, 2002).

That is why further development in civil law, private property law is only possible when taking solidary ideas into account. It also concerns digitalization of civil law, labor law, the law of intellectual property. It is written by modern civilists: "Civil legislation is in need of further socialization, and, before all, this concerns the norms, regulating the matters of socialization in private property" (Bogdanov, 2018). To that end, amplification of state private partnership, a feature of social vector of the state, is required. Moreover, state private partnership allows to effectively solve not only the matters of strengthening of social policy. "Economic safety of a state is also provided with cohesion, structural and essential unity of economy, effective level of interaction with its sectors, firstly, public and private. To achieve this goal, in conditions of domination of state finance and property, development of state private partnership, which provides integration of state and private resources to solve socially significant tasks, is very important" (Sattarova, Shokhin 2018).

Digitalization excludes the main issue of legal solidarity: paternalism and unfair distribution of social assistance. It allows to implement social support for the poor more directly, excluding dependency and passivity in entrepreneurial activity. Digitalization will provide the dialogue between state and business, which suggests not only the digital registration of the unemployed and those in need of social support, but also new forms of accounting, taxation, social start-ups: electronic sick leave, electronic mobile app "Social navigator", technologies "ExoAthlete" for the rehab of people with severe damage of motor system. All the experts are noticing the growth in interest towards digital social services offered by state and private sectors.

\section{Conclusion}

Social function of private property is often reflected in the solutions of the Constitutional Court of the Russian Federation, which is summoned to seek a reasonable balance and symmetry between the guarantees of private property, on one hand, and protection of social rights of the population - on the other. Ideas of social law, solidarity, continuity in state legal development of the country. It is them that allow to eliminate numerous flaws from the last post-soviet period of modernisation.

On one hand, contemporary law of postmodernism has even less chance to provide safety to a contemporary man. Leading scientist are talking about that, focusing attention on the problems of state legal development of Russia in the XXI century, caused by unreasoned eurocentrism in the implementation of modernisation of its economy, social area, political system (Zorkin, 2019; Baranov, Ovchinnikov 2019; Ovchinnikov, Akhrameyeva, Vorontsov, Kozhokar, Kravchenko, Mamychev, Mordovtsev, Shatkovskaya, 2019). Digital technologies not only help to speed up scientific and technological progress, but also carry new risk inside them, including an aggravation of atomization of society, individualism and particularity of society. A certain and quite substantial part of guilt is carried by liberal individualistic model of a state, which is imposed on our country by the reformers of the nineties. This model not only does not match Russian state legal traditions, in which common wealth, common cause, public interest, conciliarity dominated as the values of the law, but also modern social economic realities, which dictate the need to look for alternatives in market elements and capitalism with their endless apocalyptic consumption and irrational utilization of planet resources. The specialty of liberal democratic ideology is denial of the possibility of existence of common or basic values in its core. Only an individual and their own interests are valued.

Until the middle of the XX century the progress of the law occurred in further strengthening the conception of equality of private interest and common wealth. Even today digitalization is tuning in to the need to consider common wealth in the development of society, because the state should see its purpose in serving the society. A tendency to solidary interpretation of the ratio of public and private law, positive and intuitive law, state and autonomous law in Russian legal thinking is due to the traditional, for Russian legal culture, sociocentric topic of conciliarity and public world.

\section{References}

Alebastrova, I. A. (2016). Constitutionalism as a legal base of social solidarity. Moscow, Prospect.

Apolsky, E., Baranov, P., Mamychev, A., Mordovtsev, A., \& Ovchinnikov, A. (2017). Doctrinal and Legal Developments of the State Law Institutions in the Context of the Russian Legal Mentality (XIX- Early XX Centuries). Man in India, 97(23), 105-113.

Baranov, P. P., \& Ovchinnikov, A. I. (2019). Law in a modern changing world (based on materials of the "Round table" with international participation, Rostov-on-Don. North Caucasian juridical messenger, (2), 169-174. 
Baranov, P., Mamychev, A., Ovchinnikov, A., Komarov, A., \& Samoylichenko, A. (2017). Sociocultural (Archetypal) Transformation of Public Authority: Forms and Directions. Man in India, 97(23), 47-62.

Baranov, P., Ovchinnikov, A., Mamychev, A., \& Plotnikov, A. (2017). Elites and the Formation of Constitutionalism: The Socio-Cultural Vector of Development. Man in India, 97(23), 561-575.

Bogdanov, E. V. (2018). Socialisation of modern Russian civil law as a tendency in its development. Modern law, (1), 44-52.

Bondar, N. S. (2011). Judicial constitutionalism in Russia in light of constitutional justice. Moscow, Norma, InfraM.

Duguit, L. (2015). Social law, individual law and transformation of the state. translated from French A.S. Alekseyeva. Moscow, LENAND.

Gadzhiyev, G. (2000). Protection of property rights in Constitutional law of the Russian Federation. Constitutional law: Western European review, (4). 32-43.

Goldenweiser, A. A. (1952). Law, state and property in defense of law. Articles and speeches. New-York.

Gurvich, G. D. (2004). Philosophy and sociology of the law. Selected essays. Sankt-Petersburg, SPbGU.

Igolnikova, V. A. (2014). Social legal state. Comparative analysis of the content approaches of this concept in The West and in Russia. Government and local autonomy, (4), 3-5.

Kabyshev, S. V. (2017). Intellectual property in the system of constitutional order: comparative analysis. Actual problems of the Russian law, 141-146.

Khabriyeva, T. Y. (2018). Constitutional development: statics and dynamics (to the 25th anniversary of the Fundamental Law in Russia). Constitutional and municipal law, (12), 10-17.

Kovalevskiy, M. M. (1997). Sociology. Sankt-Petersburg, Aleteiya.

Kruss, V. I. (2017). Constitutionalism of fiscal economic duties in the Russian Federation: monograph. Moscow, NORMA, INFRA-M.

Lopukhin, A. P. (1879). State and society according to the Laws of Moses. Christian reading, (3-4).

Lushnikov, A. M., \& Lushnikova, M. V. (2007). Social law, labor law, social security law: comparative analysis. Labor law and social security law messenger. Yaroslavl, Edition. 2. 40-61.

Lushnikov, A. M., \& Lushnikova, M. V. (2009). Course of social security law. Moscow, Yustitsinform.

Lushnikov, A. M., \& Lushnikova, M. V. (2009). Labor law course (vol. 2). Moscow, Statut.

Lushnikov, A. M., \& Lushnikova, M. V. (2011). Social law: diversity of understanding and the version of the European Union. Social and legal notebook, (1), 5-21.

Medushevskaya, N. F. (2010). The idea of conciliarity and the law. The history of state and law, (13), 44-46.

Ovchinnikov, A. I., \& Ovchinnikova, S. P. (2002). Eurasional legal thinking. Rostov - on - Don. SKNTS VSH.

Ovchinnikov, A. I., Akhrameyeva, O. V., Vorontsov, S. A., Kozhokar, I. P., Kravchenko, A. G., Mamychev, A. Y., ... Shatkovskaya, T. V. (2019). Digital security of identity, society and state in conditions of globalization: juridical provision mechanisms. Review of session materials within St. Petersburg International Legal Forum 2019. The Messenger of the Juridical Faculty of Southern Federal University, 6(2), 111-122.

Petrażycki, L. I. (1913). To the question of social ideal and revival of natural law. Juridical messenger. Book. 2. 5-59.

Sattarova, N. A., \& Shokhin, S. O. (2018). Selected issues of the state administration in the field of providing financial security. The messenger of The Perm University. Juridical science, (2), 167-185. https://doi.org/10.17072/1995-4190-2018-40-167-185

Shtchekin, D. M. (2007). Tax risks and tendencies in development of Tax law. Moscow. Statut.

Simashenkov, P. D. (2016). Transparency" and sacredness of the Russian power in historical perspective. Government and local autonomy, (6), 60-64.

Sinyukov, V. N. (1994). Russian legal system. Introduction to the general theory. Saratov, Polygraphist.

Sorokin, V. V. (2007) The concept and essence of the law in spiritual culture of Russia. Moscow.

Tal, L. S. (1915). Juridical nature of organization or internal order of enterprise. Moscow. 
Tal, L. S. (1916). Essays on industrial law. Moscow.

Tarusina, N. N., Lushnikov, A. M., \& Lushnikova, M. V. (2017). Social agreements in the law. Moscow, Prospect.

Timofeyev, N. S. (2018). Tendencies and directions in the conceptional development of local autonomy in Russia. Constitutional and municipal law, (10), 52-63.

Titova, E. V. (2018). To the question of constitutional legal concept of interaction between the state and a man. Lex russica, (11), 69-82.

Vasilyev, A. A. (2012). Legal doctrine as a source of the law. Public legal research, (2), 38-75.

Vasilyev, A. A. (2015). Conciliar statehood in Russia and parliamentarism in western Europe: comparative legal research. Constitutional and municipal law, (8), 48-51.

Velichko, A. M. (1999). State ideals in Russia and the West. Parallels of legal culture. Sankt-Petersburg, SPbGU press.

Zorkin, V. D. (2018a). Justice - the imperative of civilization of the law. Russian newspaper. https://doi.org/10.31857/S004287440004029-6

Zorkin, V. D. (2018b). The letter and spirit of the Constitution. Retrieved from https://rg.ru/2018/10/09/zorkinnedostatki-v-konstitucii-mozhno-ustranit-tochechnymi-izmeneniiami.html

Zorkin, V. D. (2019). The law of metamodernism: formulation of the problem. A lecture on the IX St. Petersburg International Legal Forum. Retrieved from https://rg.ru/2019/05/16/zorkin-priverzhennost-vernoj-filosofiiprava-pozvoliaet-tvorit-dobro.html

\section{Copyrights}

Copyright for this article is retained by the author(s), with first publication rights granted to the journal.

This is an open-access article distributed under the terms and conditions of the Creative Commons Attribution license (http://creativecommons.org/licenses/by/4.0/). 